\title{
The effect of accounting education reform on quality of accounting services: The case of Kosovo
}

\author{
Safet Abdullahu a and Nexhmie Berisha Vokshi ${ }^{b^{*}}$
}

aniversity of Mitrovica "Isa Boletini", Kosovo

${ }^{b}$ University of Pristina "Hasan Pristina", Kosovo

\section{H R O N I C L E \\ A B S T R A C T}

Article history:

Received: February 27, 2021

Received in revised format:

April 292021

Accepted: May 16, 2021

Available online:

May 18, 2021

Keywords:

Accounting education

Challenges

Reforms

Prospects
Accounting education is the main factor that is influencing the improvement of the state of accounting services and the quality of accounting. The XXI century has influenced great changes in different fields, applying different tools of technology and for this reason, the field of accounting education has faced reforms and adaptation to new forms of application. The adaptation of accounting education to ISCE is a very important factor in the adaptation of accounting services worldwide. For this reason, research was presented, which measured the impact of accounting education reforms on accounting services in Kosovo, i.e. the adaptation of accounting education programs to ISCE and curricula. Professors from accounting universities and professors of accounting in high schools in Kosovo were surveyed for this. The sample was random, with one in three teachers selected. Data were analyzed through the SPSS program, while regression and correlation method was used to validate the hypothesis. Based on the results we see that the implementation of reforms in the framework of accounting education and adaptation to ISCE has an impact on the quality of accounting services at both university level (p-value $<0.01$ ) and secondary level ( $p$-value $<0.01$ ). Correlation analysis shows that we have a significant relationship between the implementation of accounting education reforms and the quality of accounting services $($ rho $=.628 * *, p$-value $<0.01)$ at both university and secondary level (rho $=.652 * *$, p-value $<0.01)$. Finally, the implementation of accounting education reforms is well on the way to the development of accounting education in Kosovo, so we must have a proactive approach to the development of this field.

\section{Introduction}

Langenderfer (1987) pointed out that the early formation of accounting and the accounting profession was followed by the American Revolution. Education in the field of accounting dates back to the late 1700s and early 1800s following the English tradition of developing "Student internships" where young accountants learned by observing experienced accountants. In a study conducted by Sikka et al. (2007), it has been pointed out that organizations of the accounting profession, which provide lifelong accounting education to accountants and auditors are exposed to the risks associated with the failures of large financial companies, crises, and financial scandals. In this study, the opinion is expressed that the above phenomena are evidence of the failure of continuing accounting education throughout the professional activity of accountants. Parker (2007) noted that universities focus on accounting techniques, rules, standards, and auditing by treating accounting as a discipline and numerical science. The professional competencies and responsibilities of economists practicing the accounting profession have changed significantly since the 1990s. Their role is no longer limited to recording, summarizing, and reporting transactions. (Latridis, 2010) based on data collected from entities listed on the London Stock Exchange concluded that the implementation of IFRSs has had a positive impact on financial performance (measured by profitability

* Corresponding author.

E-mail address: nexhmie.berisha@uni-pr.edu (N. B. Vokshi)

(C) 2021 by the authors; licensee Growing Science, Canada doi: 10.5267/j.ac.2021.5.008 
and growth potential). Given the great importance of accounting education, we have presented a constructive approach to the literature browsing on accounting education over the years and in different countries of the world, where I will present to the readers with special importance the impact of accounting education reforms in Kosovo and their impact on improving the quality of accounting education.

\section{Literature review}

Sangster and Scataglinibelghitar (2010) interpret accounting education as a manual for businessmen on how to keep accounts, whereas Sangster (2015) presents some detailed evidence of a previous manual of bookkeeping from the year 1476 by Marino de Raphael, in which he describes it as an early treaty known for its dual bookkeeping. Edwards (2011) examines accounting education in Britain in the early period (1550-1800) at the time of rapid trade expansion and early industrialization of that time. In this regard, he notes that accounting education is not yet the subject of significant study by accounting experts. So, he significantly shows that his discussion is not limited to a narrow view of accounting education, but discusses teachers and their institutions, as well as what was taught or notes that often they practiced accounting were self-taught, so this special issue adopts a broad definition of accounting education. Parker et al. (2011) say that equally important for the discussion of international standards of accounting education is the issue of quality of accounting services which are provided in various forms. Therefore, it is required to pay special attention to quality in addition to the reforms that are undertaken to adapt the curriculum and educational programs of accounting education in secondary and university education. According to Evans (2011), quality is also articulated as a credible social symbol and attractive market, where the increase in the number of students, graduates, and participants in the profession is pursued as a revenue key for all parties involved. Universities continue to operate degree fields that produce strong student demands as vital revenue generators, aimed at minimizing operating costs and maximizing revenue streams. Sikka et al. (2007) presents the case in the United States, where it is the first country which identified the need for reforms in accounting education, as accounting experts felt that curricula and pedagogical considerations are placing great emphasis on the technical aspects of accounting, affecting education generally. There was a lack of critical thinking and problem solving, communication, and many other general skills that were considered essential for entry-level accountants. The Accounting Education Change Commission (AECC) was formed in 1989 with a mandate to address this problem. This issue was mentioned by many authors (Langenderfer, 1987) in the United States from the 1980 s to the $1990 \mathrm{~s}$. So even after implementing the 150 -semester requirement of the American Institute of Certified Public Accountants (AICPA) in 2000, the problem of practitioners' grievance was the university accounting curriculum to train students in technical memorization of grades at the expense of the wider business, the communication and analytical skills they needed in a real world. (Mayper et al., 2005) they reported on the severity of the problems faced by accounting education as a result of changes in business from globalization, technology, and the power of investors in capital markets. Sikka et al. (2007) describe the challenges faced by accounting education and the profession, most of which were related to the curriculum and related to the teaching approach and were covered in the AECC initiatives. Burnett (2003) identified four assessed professional skills necessary for accounting graduates, being analytical/critical thinking, written communication, oral communication, and decision making. Again, these were suggested by the AECC. Noble and Smith (2015) noted that commodification is in stark contrast to the traditional objective of education, which has been the integration of knowledge (self-knowledge) - to create civic knowledge (as opposed to trained). Throughout the 20th century, institutional theorists repeatedly warned that financial interests had gained control of higher education institutions in the United States, causing the loss of higher education autonomy. Management accountants work in cross-functional teams and are actively involved in decision-making. This requires them to spend more time communicating with others, which means that good interpersonal skills are essential to success. Parker (2007) claimed that corporatism has resulted in sub-selection, contamination, and simulation of business education in the United States. He suggests that business education has become transparent in its desire to serve corporate interests. The language of business accreditation standards supports Dugger's (1980)'s claim that the primary role of higher education has been to produce a supply of trained and disciplined corporate employment specialists rather than to produce an informed citizen. Noble and Smith (2015) show that the knowledge, the most important skills needed for success are those of communication, analytics, technical accounting knowledge, and understanding of how the business works. So market expectations showed a link between the most important skills and competencies of accountants and financiers. Gaffikin (2008) emphasizes that competency-based education is specified in terms of outcomes, or what an individual can achieve, rather than an individual's knowledge or skills. This type of education has been subject to changing accounting education in recent decades. However, defining competencies has not been easy. Some alternative definitions and philosophies underlie competency-based approaches and visions of how competencies are assessed. In the context of the European Qualifications Framework for Lifelong Learning (BE, 2008), competencies are distinguished by knowledge and skills and are described in terms of responsibility and autonomy. Moyes et al. (2000) pointed out that properly implemented rubrics can be useful in assessing the achievement of learning objectives for students, courses, and programs. U diskutua për zhvillimin e duhur të rubrikës. A set of examples of rubrics designed to assess three learning objectives was presented: (1) accounting measurement, (2) research, and (3) critical thinking. Bergner et al. (2016) examined the ability of multiple-choice (MCE) questions to discriminate against student understanding better than multiple-choice (non-multiple choice) questions. Lindsay (2016) developed a framework for professional learning (presented as a pyramid) that distinguishes between 'informed', 'competent 'and' complete 'professionals. The nine interrelated elements of the framework, starting at the top of the pyramid and continuing downwards, are (1) courses and technical updates, (2) learning with/from others, (3) learning at work, (4) learning through reflection, (5) engagement, (6) exploration, (7) experimentation, (8) positive attitude, and (9) self- 
confidence. He came up with nine elements related to 'learning about professional skills' and' learning about career adaptation, 'which are similar to 'lifelong learning' in other frameworks or position statements.

\subsection{Aim of research}

The purpose of the research is to analyze the challenges and the current state of accounting education in Kosovo, where I focused on measuring the impact of accounting education reforms and adaptation to SNE in increasing the quality of accounting services.

\subsection{Research question}

How necessary are reforms in accounting education and adaptation of curricula to SNEs to improve accounting services in Kosovo?

\subsection{Hypothesis}

Implementation of reforms in the field of accounting education and adaptation to SNEs has an impact on the quality of accounting services.

\section{Methodology of research}

The research was conducted with high school teachers and university professors in the Republic of Kosovo, while a total of 66 respondents participated in the research, of which 36 university teachers and 30 high school teachers. The sample was random and involved every third teacher, i.e., accounting teachers. The model used is linear regression: $\mathbf{Y}_{\mathbf{i}, \mathbf{t}}=\boldsymbol{\beta}_{\mathbf{0}}+\boldsymbol{\beta}_{\mathbf{1}} \mathbf{Z R} \mathbf{P}_{\mathbf{i}, \mathbf{t}}$ $+{ }^{+}$i,t. The data were analyzed through the SPSS program, and to measure the challenges we initially presented in a descriptive form the research results, which were analyzed through a questionnaire. The test was then used through the simple linear regression model and the Spearman correlation.

\subsection{Research instrument}

The research instrument is composed of the demographic part (institution where they work, region, date of the survey, then gender, age, place of residence, position, sector, and average annual income), while in the second part the questions are organized on the compatibility of accounting education and implementation of accounting education reforms, as well as measuring the quality of accounting services.

\section{Logical concept of research}

The logical concept of the research is realized based on independent and dependent variables, while the control variables compare the impact of reforms and program adaptation with SNEs.

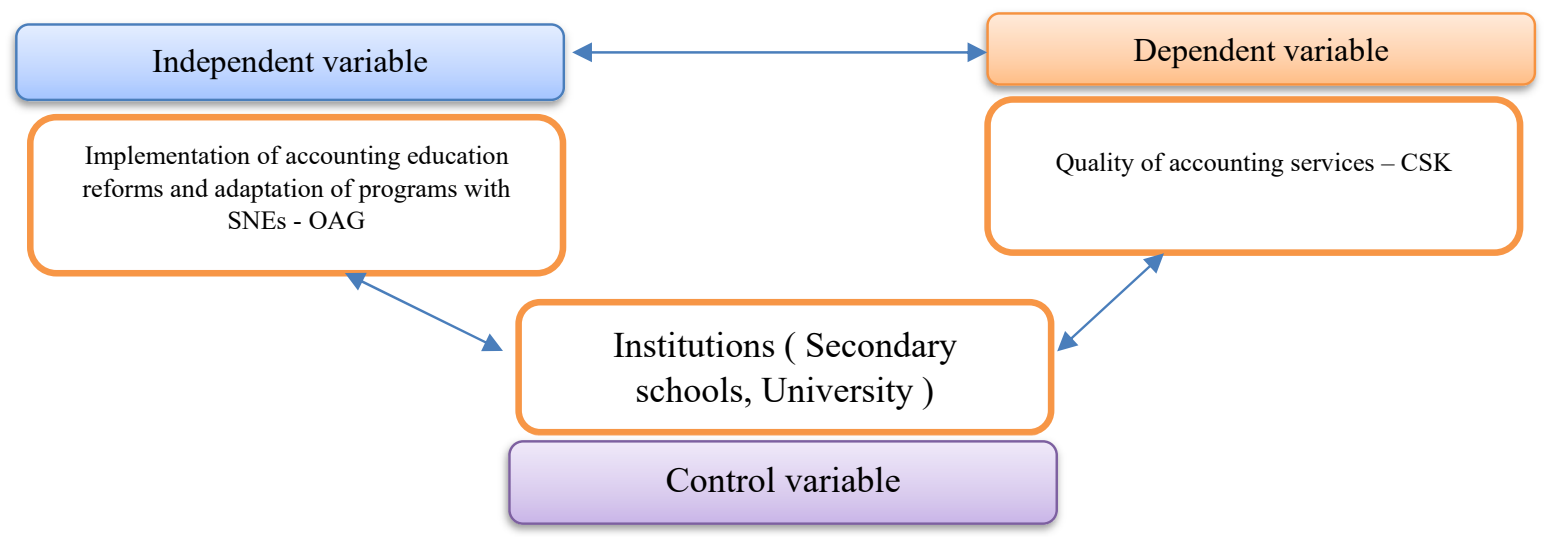

Fig. 1. Logical concept of research

\section{Empiric results}

The analyzes were performed through the SPSS program, and initially descriptive data on the participation of teachers at the level of vocational and university schools were presented. Hypothesis testing was performed through the linear regression and Spearman correlation method which are presented in the following section.

\subsection{Descriptive statistics}

A total of 36 teachers from public and private universities in Kosovo participated in the research or $28.6 \%$ of the sample, 30 teachers were from public high schools or $23.8 \%, 40$ other accountants from professional associations or $31.7 \%$ and 20 
participants were the first level as rectors, deans, and directors of associations and vocational high schools or $15.9 \%$ of the sample. The research was included throughout Kosovo. 73 males or $57.9 \%$ participated in the research, while 53 were females or $42.1 \%$, while 101 of them were from urban areas or $80.2 \%$, and 25 from rural areas or $19.8 \%$. From the public sector were 107 of them or $84.9 \%$ and 19 of the private ones or $15.1 \%$. With an average annual salary of $4000-5000$ Euros were 14 respondents or $11.1 \%$, then 59 respondents were with a salary of 5001-10.000 Euros or 46.8\%, 28 with an average annual salary of $100001-15000$ Euros or $22.2 \%, 15$ with an average annual salary of $150001-20000$ Euros or $11.9 \%$ and 10 others with an average annual salary over 20,000 thousand Euros. With a bachelor's degree, there were 11 respondents or $8.7 \%$, with master degree qualification 68 respondents or 54\%, 4 of them Ph.D. candidates or 3.2\%, and 43 others with the title of doctor of science or $34.1 \%$.

Table 1

Descriptive statistics

\begin{tabular}{|c|c|c|c|c|c|}
\hline Institutions & $\mathrm{N}$ & $\%$ & Higher academic level & $\mathrm{N}$ & $\%$ \\
\hline Universities & 36 & 28.6 & Bachelor & 11 & 8.7 \\
\hline High School & 30 & 23.8 & Master & 68 & 54.0 \\
\hline Organizations & 40 & 31.7 & Ph.D. Candidate & 4 & 3.2 \\
\hline Managerial level & 20 & 15.9 & Doctoral & 43 & 34.1 \\
\hline City & $\mathrm{N}$ & $\%$ & Sector & $\mathrm{N}$ & $\%$ \\
\hline Drenas & 4 & 3.2 & Public & 107 & 84.9 \\
\hline Ferizaj & 11 & 8.7 & Private & 19 & 15.1 \\
\hline Gjakovë & 13 & 10.3 & & & \\
\hline Gjilan & 8 & 6.3 & Average annual income & $\mathrm{N}$ & $\%$ \\
\hline Gllogoc & 2 & 1.6 & $4,000-5,000$ Euro & 14 & 11.1 \\
\hline Kamenicë & 2 & 1.6 & $5,001-10,000$ Euro & 59 & 46.8 \\
\hline Mitrovicë & 20 & 15.9 & 10,001-15,000 Euro & 28 & 22.2 \\
\hline Obiliq & 3 & 2.4 & 15,001-20,000 Euro & 15 & 11.9 \\
\hline Pejë & 15 & 11.9 & Mbi 20,000 Euro & 10 & 7.9 \\
\hline Prishtinë & 42 & 33.3 & & & \\
\hline Prizren & 2 & 1.6 & & & \\
\hline Skenderaj & 4 & 3.2 & & & \\
\hline Gender & $\mathrm{N}$ & $\%$ & Settlement & $\mathrm{N}$ & $\%$ \\
\hline Male & 73 & 57.9 & Urban & 101 & 80.2 \\
\hline Female & 53 & 42.1 & Rural & 25 & 19.8 \\
\hline
\end{tabular}

\subsection{Questionnaire results in high schools and universities}

In the following section, we have presented the descriptive results of the research, which have been classified by making a comparison between the opinion of vocational high school teachers and universities. We look at the general knowledge of SNEs, we see that university teachers show a higher level of knowledge about SNEs, and also in terms of the compliance of SNEs with the programs and curricula they apply, University teachers say they have higher compliance. We see that both sides, both university, and high school teachers, seek support to implement the SNEs, but in this case, high school teachers all agree that they need help, and it is seen that they do not have any support from support bodies or this support is too low. From the answers, we understand that in the university SNEs find a wider application, while in high schools this application is dim, while everyone thinks that other and favorable conditions should be created to implement accounting education in Kosovo in the report. with SNEs.

Table 2

General knowledge on SNEs

\begin{tabular}{|c|c|c|c|c|}
\hline \multirow{4}{*}{ General knowledge of SNEs } & \multicolumn{4}{|c|}{ Groups } \\
\hline & \multicolumn{2}{|c|}{ Universities } & \multicolumn{2}{|c|}{ High School } \\
\hline & Yes & No & Yes & No \\
\hline & $\%$ & $\%$ & $\%$ & $\%$ \\
\hline Do you know international education standards SNEs? & $83.3 \%$ & $16.7 \%$ & $63.3 \%$ & $36.7 \%$ \\
\hline Is your accountability program or curriculum compliant with SNEs? & $88.9 \%$ & $11.1 \%$ & $53.3 \%$ & $46.7 \%$ \\
\hline Do you need support to implement SNEs in accounting curricula? & $75.0 \%$ & $25.0 \%$ & $100.0 \%$ & $0.0 \%$ \\
\hline Do you have any support from the relevant bodies to implement the SNEs? & $11.1 \%$ & $88.9 \%$ & $16.7 \%$ & $83.3 \%$ \\
\hline Are SNEs implemented in educational institutions in Kosovo? & $77.8 \%$ & $22.2 \%$ & $30.0 \%$ & $70.0 \%$ \\
\hline $\begin{array}{l}\text { Do you think that other favorable conditions should be created for the implementation of accounting } \\
\text { education in Kosovo, concerning SNEs? }\end{array}$ & $94.4 \%$ & $5.6 \%$ & $96.7 \%$ & $3.3 \%$ \\
\hline
\end{tabular}

Regarding the requirements for entering the accounting education program, we see that based on the opinion of university and high school teachers, accounting or financial knowledge is required to be declared a winner in the branches of finance or accounting and we have a higher level, low balance of the level of knowledge required and entry into study programs.

We see that in terms of profeaasional skills, teachers say that the program is designed concerning SNEs, whereas in high schols we do not have such a level of compliance. 
Table 3

$\underline{\text { Requirements for entry into an accounting education program }}$

\begin{tabular}{|c|c|c|c|c|}
\hline \multirow{4}{*}{ Requirements for entry into an accounting education program } & \multicolumn{4}{|c|}{ Groups } \\
\hline & \multicolumn{2}{|c|}{ Universities } & \multicolumn{2}{|c|}{ Universities } \\
\hline & Yes & Yes & Yes & Yes \\
\hline & $\%$ & $\%$ & $\%$ & $\%$ \\
\hline $\begin{array}{l}\text { Are accounting or financial skills required to be declared a winner in the branches of Finance and Ac- } \\
\text { counting }\end{array}$ & $86.1 \%$ & $13.9 \%$ & $100.0 \%$ & $0.0 \%$ \\
\hline $\begin{array}{l}\text { Is there a balance between the level of knowledge/education required at the initial moment of entering } \\
\text { the study programs }\end{array}$ & $83.3 \%$ & $16.7 \%$ & $63.3 \%$ & $36.7 \%$ \\
\hline
\end{tabular}

Table 4

Professional skills

Professional Skills

\begin{tabular}{cccc}
\multicolumn{4}{c}{ Groups } \\
\hline \multicolumn{2}{c}{ Universities } & \multicolumn{2}{c}{ Universities } \\
\hline Yes & Yes & Yes & Yes \\
\hline$\%$ & $\%$ & $\%$ & $\%$ \\
\hline $91.7 \%$ & $8.3 \%$ & $66.7 \%$ & $33.3 \%$
\end{tabular}

Our study programs designed to enhance knowledge, understanding, application, analysis, synthesis (combin-

ing knowledge from several areas, to predict and draw conclusions), and to evaluate accounting and auditing

issues

At the university we have much broader compliance of standards in terms of mathematical applications, statistics, and information technology skills, risk analysis, measurement, reporting, and compliance with legal requirements, while in high schools this level is lower, i.e., we have a lower level of implementation of technical and functional skills.

Table 5

Technical and financial skills

Technical and functional skills

\begin{tabular}{cccc}
\multicolumn{4}{c}{ Groups } \\
\hline \multicolumn{3}{c}{ Universities } & \multicolumn{2}{c}{ Universities } \\
\hline Yes & Yes & Yes & Yes \\
\hline$\%$ & $\%$ & $\%$ & $\%$ \\
\hline $88.9 \%$ & $11.1 \%$ & $53.3 \%$ & $46.7 \%$ \\
$86.1 \%$ & $13.9 \%$ & $60.0 \%$ & $40.0 \%$ \\
$86.1 \%$ & $13.9 \%$ & $50.0 \%$ & $50.0 \%$ \\
$100.0 \%$ & $0.0 \%$ & $73.3 \%$ & $26.7 \%$ \\
$100.0 \%$ & $0.0 \%$ & $73.3 \%$ & $26.7 \%$ \\
\hline
\end{tabular}

In personal skills concerning study programs, we see that in the university we have a much higher level of achievement of personal skills, so study programs offer an appropriate level of achievement of personal skills, namely the level of self-government, initiative for where the difference is relatively large between universities and high schools, and the biggest difference is in the ability to choose and set priorities within resources, and in terms of skepticism we see that we have the same level of the opinion of teachers of universities and high schools.

Table 6

Personal skills study programs emphasize the skills

Personal Skills Study programs emphasize the skills of:

Self-government

Initiative to learn independently

Ability to select and set priorities within limited resources and Organize work to meet deadlines

Professional skepticism.

\begin{tabular}{cccc}
\multicolumn{4}{c}{ Groups } \\
\hline \multicolumn{2}{c}{ Universities } & \multicolumn{2}{c}{ Universities } \\
\hline Yes & Yes & Yes & Yes \\
\hline$\%$ & $\%$ & $\%$ & $\%$ \\
\hline $80.6 \%$ & $19.4 \%$ & $73.3 \%$ & $26.7 \%$ \\
$83.3 \%$ & $16.7 \%$ & $63.3 \%$ & $36.7 \%$ \\
$83.3 \%$ & $16.7 \%$ & $30.0 \%$ & $70.0 \%$ \\
$72.2 \%$ & $27.8 \%$ & $73.3 \%$ & $26.7 \%$ \\
\hline
\end{tabular}

We consider communication skills to be at a relatively similar level in both university and vocational high school programs, namely working with others in a consultative process, working in groups, resolving professional issues and situations, as well as in the aspect of presenting and defending views.

Table 7

Communication skills

\section{Communication Skills}

Working with others in a consultative process, to deal with and resolve conflicts

Group work

Resolving professional issues and situations

Present, discuss, report, and advocate views effectively in formal, informal, written, and verbal commu-

\begin{tabular}{cccc}
\hline \multicolumn{4}{c}{ Groups } \\
\hline \multicolumn{2}{c}{ Universities } & \multicolumn{2}{c}{ Universities } \\
\hline Yes & Yes & Yes & Yes \\
\hline$\%$ & $\%$ & $\%$ & $\%$ \\
\hline $97.2 \%$ & $2.8 \%$ & $93.3 \%$ & $6.7 \%$ \\
$86.1 \%$ & $13.9 \%$ & $90.0 \%$ & $10.0 \%$ \\
$100.0 \%$ & $0.0 \%$ & $83.3 \%$ & $16.7 \%$ \\
$91.7 \%$ & $8.3 \%$ & $83.3 \%$ & $16.7 \%$ \\
& & &
\end{tabular}
nication 
We see that even in the compliance of study programs with the organization and management of the business, we have a professional and good approach of university and high schools, i.e., university and high school programs with strategic planning, project management, and human resource management. We also match the ability to organize and delegate tasks, leadership, and professional judgment.

\section{Table 8}

Business organization and management

\begin{tabular}{|c|c|c|c|c|}
\hline \multirow{4}{*}{ Business organization and management } & \multicolumn{4}{|c|}{ Groups } \\
\hline & \multicolumn{2}{|c|}{ Universities } & \multicolumn{2}{|c|}{ Universities } \\
\hline & Yes & Yes & Yes & Yes \\
\hline & $\%$ & $\%$ & $\%$ & $\%$ \\
\hline Strategic planning, project management, human resource management, & $94.4 \%$ & $5.6 \%$ & $80.0 \%$ & $20.0 \%$ \\
\hline Abilities to organize and delegate tasks, to motivate and develop staff & $91.7 \%$ & $8.3 \%$ & $70.0 \%$ & $30.0 \%$ \\
\hline Leadership & $100.0 \%$ & $0.0 \%$ & $76.7 \%$ & $23.3 \%$ \\
\hline Professional judgment & $100.0 \%$ & $0.0 \%$ & $93.3 \%$ & $6.7 \%$ \\
\hline
\end{tabular}

We see that in the application, the opinion of university teachers does not differ much from those of high schools, so exactly we have the consistency of identifying and solving problems, then conducting appropriate technical research, group work, and data collection and evaluation.

Table 9

Application

\begin{tabular}{|c|c|c|c|c|}
\hline & \multicolumn{4}{|c|}{ Groups } \\
\hline Annliontion & \multicolumn{2}{|c|}{ Universities } & \multicolumn{2}{|c|}{ Universities } \\
\hline Application & Yes & Yes & Yes & Yes \\
\hline & $\%$ & $\%$ & $\%$ & $\%$ \\
\hline Identify and solve problems & $100.0 \%$ & $0.0 \%$ & $73.3 \%$ & $26.7 \%$ \\
\hline Conducting appropriate technical research & $94.4 \%$ & $5.6 \%$ & $93.3 \%$ & $6.7 \%$ \\
\hline Group work & $88.9 \%$ & $11.1 \%$ & $93.3 \%$ & $6.7 \%$ \\
\hline Data collection and evaluation & $88.9 \%$ & $11.1 \%$ & $90.0 \%$ & $10.0 \%$ \\
\hline
\end{tabular}

We see that in enforceability in an audit environment, in addition to other skills teachers say that there is also involvement in the implementation of auditing standards and guidelines, evaluation of implementation, demonstration, application of professional judgment, and coping with conflict resolution. this involvement is wide at both levels of education, both at the university and in vocational high schools in Kosovo.

Table 10

Applicability in an audit environment

\begin{tabular}{|c|c|c|c|c|}
\hline \multirow{4}{*}{ Applicability in an audit environment } & \multicolumn{4}{|c|}{ Groups } \\
\hline & \multicolumn{2}{|c|}{ Universities } & \multicolumn{2}{|c|}{ Universities } \\
\hline & Yes & Yes & Yes & Yes \\
\hline & $\%$ & $\%$ & $\%$ & $\%$ \\
\hline Implementation of auditing standards and guidelines & $100.0 \%$ & $0.0 \%$ & $93.3 \%$ & $6.7 \%$ \\
\hline Evaluate the implementation of financial reporting standards & $100.0 \%$ & $0.0 \%$ & $50.0 \%$ & $50.0 \%$ \\
\hline Demonstrating professional skepticism & $77.8 \%$ & $22.2 \%$ & $76.7 \%$ & $23.3 \%$ \\
\hline Application of professional judgment & $88.9 \%$ & $11.1 \%$ & $86.7 \%$ & $13.3 \%$ \\
\hline Confronting and resolving conflicts & $94.4 \%$ & $5.6 \%$ & $96.7 \%$ & $3.3 \%$ \\
\hline
\end{tabular}

\section{Table 11}

Values, ethics and attitudes

\begin{tabular}{|c|c|c|c|c|}
\hline \multirow{4}{*}{ Values, Ethics, and Attitudes } & \multicolumn{4}{|c|}{ Groups } \\
\hline & \multicolumn{2}{|c|}{ Universities } & \multicolumn{2}{|c|}{ Universities } \\
\hline & Yes & Yes & Yes & Yes \\
\hline & $\%$ & $\%$ & $\%$ & $\%$ \\
\hline The Nature of Ethics & $100.0 \%$ & $0.0 \%$ & $93.3 \%$ & $6.7 \%$ \\
\hline $\begin{array}{l}\text { Compliance with the basic ethical principles of integrity, objectivity, commitment to professional } \\
\text { competence and due diligence and confidentiality }\end{array}$ & $100.0 \%$ & $0.0 \%$ & $93.3 \%$ & $6.7 \%$ \\
\hline Professional conduct and adherence to technical standards & $100.0 \%$ & $0.0 \%$ & $76.7 \%$ & $23.3 \%$ \\
\hline The concept of independence, skepticism, accountability, and public expectations & $94.4 \%$ & $5.6 \%$ & $86.7 \%$ & $13.3 \%$ \\
\hline Ethics and profession: social responsibility & $100.0 \%$ & $0.0 \%$ & $96.7 \%$ & $3.3 \%$ \\
\hline Ethics and law, including the relationship between law, regulation, and the public interest & $100.0 \%$ & $0.0 \%$ & $66.7 \%$ & $33.3 \%$ \\
\hline Consequences of unethical behavior towards the individual, profession, and society in general & $100.0 \%$ & $0.0 \%$ & $93.3 \%$ & $6.7 \%$ \\
\hline Ethics related to business and good governance & $100.0 \%$ & $0.0 \%$ & $93.3 \%$ & $6.7 \%$ \\
\hline Ethics and accounting professionals: conflicts of interest, ethical dilemmas, and their resolution & $88.9 \%$ & $11.1 \%$ & $100.0 \%$ & $0.0 \%$ \\
\hline $\begin{array}{l}\text { Individuals must apply professional values, ethics, and attitudes before taking on the role of a } \\
\text { PROFESSIONAL AUDITOR. }\end{array}$ & $94.4 \%$ & $5.6 \%$ & $100.0 \%$ & $0.0 \%$ \\
\hline
\end{tabular}

In values, attitudes and attitudes, i.e., if this component is in higher and secondary education, teachers from both levels express that it is applicable and is included in study programs. Exactly the nature of ethics, compliance with the basic principles of 
integrity ethics, professional conduct, ethics, and profession, as well as ethics and law. Ethics related to business and professionals are also included. This shows that in university and high school study programs, we have a satisfactory application of standards, where values, ethics, and attitudes are incorporated and enable students to be trained. We see that in the university we have a wide range of subjects, as well as in vocational high schools. This shows that the curricula in Kosovo have a wide involvement in the implementation of SNE standards and this shows seriousness and good managerial skills.

Table 12

Curricula and study programs

\begin{tabular}{|c|c|c|c|c|}
\hline \multirow{4}{*}{ Curricula and study programs } & \multicolumn{4}{|c|}{ Groups } \\
\hline & \multicolumn{2}{|c|}{ Universities } & \multicolumn{2}{|c|}{ Universities } \\
\hline & Yes & Yes & Yes & Yes \\
\hline & Row N \% & Row N\% & Row N \% & Row N \% \\
\hline Accounting and Financial Reporting & $100.0 \%$ & $0.0 \%$ & $90.0 \%$ & $10.0 \%$ \\
\hline Management Accounting & $75.0 \%$ & $25.0 \%$ & $76.7 \%$ & $23.3 \%$ \\
\hline Control & $100.0 \%$ & $0.0 \%$ & $70.0 \%$ & $30.0 \%$ \\
\hline Taxation & $69.4 \%$ & $30.6 \%$ & $86.7 \%$ & $13.3 \%$ \\
\hline Business and Commercial Legislation & $83.3 \%$ & $16.7 \%$ & $46.7 \%$ & $53.3 \%$ \\
\hline Audit and Security Services & $97.2 \%$ & $2.8 \%$ & $96.7 \%$ & $3.3 \%$ \\
\hline Financial Management & $88.9 \%$ & $11.1 \%$ & $83.3 \%$ & $16.7 \%$ \\
\hline Ethics and Professional Values & $94.4 \%$ & $5.6 \%$ & $83.3 \%$ & $16.7 \%$ \\
\hline
\end{tabular}

Organizational and business knowledge is also included in the fields of study or study programs offered at universities and vocational schools as separate topics or chapters. We see that this provides a broad application of SNE standards and enables pupils and students to achieve appropriate professional skills.

Table 13

Inclusion of SNEs in study programs

\begin{tabular}{|c|c|c|c|c|}
\hline \multirow{4}{*}{ Inclusion of SNEs in study programs } & \multicolumn{4}{|c|}{ Groups } \\
\hline & \multicolumn{2}{|c|}{ Universities } & \multicolumn{2}{|c|}{ Universities } \\
\hline & Yes & Yes & Yes & Yes \\
\hline & Row N \% & Row N \% & Row N \% & Row N \% \\
\hline Economics & $63.9 \%$ & $36.1 \%$ & $73.3 \%$ & $26.7 \%$ \\
\hline The environment where the business operates & $77.8 \%$ & $22.2 \%$ & $40.0 \%$ & $60.0 \%$ \\
\hline Corporate governance & $83.3 \%$ & $16.7 \%$ & $76.7 \%$ & $23.3 \%$ \\
\hline Ethics in business & $72.2 \%$ & $27.8 \%$ & $76.7 \%$ & $23.3 \%$ \\
\hline Financial markets & $100.0 \%$ & $0.0 \%$ & $63.3 \%$ & $36.7 \%$ \\
\hline Quantitative method & $97.2 \%$ & $2.8 \%$ & $60.0 \%$ & $40.0 \%$ \\
\hline Strategic management and decision making & $72.2 \%$ & $27.8 \%$ & $96.7 \%$ & $3.3 \%$ \\
\hline Marketing & $61.1 \%$ & $38.9 \%$ & $56.7 \%$ & $43.3 \%$ \\
\hline International Business and Globalization & $83.3 \%$ & $16.7 \%$ & $86.7 \%$ & $13.3 \%$ \\
\hline Organizational behavior & $66.7 \%$ & $33.3 \%$ & $83.3 \%$ & $16.7 \%$ \\
\hline
\end{tabular}

Table 14

The information technology component in the curriculum includes

\begin{tabular}{|c|c|c|c|c|}
\hline \multirow{4}{*}{$\begin{array}{l}\text { The information technology component in the curricu- } \\
\text { lum includes }\end{array}$} & \multicolumn{4}{|c|}{ Groups } \\
\hline & \multicolumn{2}{|c|}{ Universities } & \multicolumn{2}{|c|}{ Universities } \\
\hline & Yes & Yes & Yes & Yes \\
\hline & Row N \% & Row N \% & Row N \% & Row N \% \\
\hline General IT Knowledge & $88.9 \%$ & $11.1 \%$ & $73.3 \%$ & $26.7 \%$ \\
\hline IT knowledge control & $66.7 \%$ & $33.3 \%$ & $56.7 \%$ & $43.3 \%$ \\
\hline Control of IT Competencies & $66.7 \%$ & $33.3 \%$ & $53.3 \%$ & $46.7 \%$ \\
\hline Competencies of IT users & $72.2 \%$ & $27.8 \%$ & $53.3 \%$ & $46.7 \%$ \\
\hline $\begin{array}{l}\text { A combination of management competencies, evalu- } \\
\text { ators, or information systems designers }\end{array}$ & $66.7 \%$ & $33.3 \%$ & $60.0 \%$ & $40.0 \%$ \\
\hline
\end{tabular}

We see that even in the information technology component in the curriculum, they include general IT knowledge, knowledge control, competency control, as well as combining competencies with directions, assessment, or information systems designers.

\subsection{Compliance of accounting education in Kosovo with international education standards (SNE)}

University teachers say that accounting education should be changed to adapt to SNEs, but this opinion is not shared by teachers of vocational high schools in Kosovo, and they do not agree at all with the opinion that accounting education does not meet the basic criteria of SNE so study programs in Kosovo have a good alignment with SNEs. The vast majority disagree or are neutral with the opinion that accounting education does not enable vocational training of students in Kosovo, while we have a relative agreement with the fact that accounting education in Kosovo has the possibility of achieving SNEs at the level of vocational and university education. Implementation in practice is considered to be a problem and the lack of syllogistic compliance of mid-level and university study programs with SNEs. 
Table 15

Compliance of accounting education in kosovo with international education standards (sne)

\begin{tabular}{|c|c|c|c|c|c|c|c|c|c|c|}
\hline & \multicolumn{10}{|c|}{ Groups } \\
\hline & \multicolumn{5}{|c|}{ Universities } & \multicolumn{5}{|c|}{ High School } \\
\hline & $\begin{array}{c}\text { I do not } \\
\text { agree at all }\end{array}$ & $\begin{array}{l}\text { I don't } \\
\text { know }\end{array}$ & Neutral & Agree & Agree & $\begin{array}{l}\text { I do not } \\
\text { agree at } \\
\text { all }\end{array}$ & $\begin{array}{l}\text { I do not } \\
\text { know }\end{array}$ & Neutral & Agree & Agree \\
\hline & $\%$ & $\%$ & $\%$ & $\%$ & $\%$ & $\%$ & $\%$ & $\%$ & $\%$ & $\%$ \\
\hline $\begin{array}{l}\text { Accounting education in Kosovo } \\
\text { needs to be changed to adapt to } \\
\text { SNEs }\end{array}$ & $0.0 \%$ & $8.3 \%$ & $33.3 \%$ & $19.4 \%$ & $38.9 \%$ & $13.3 \%$ & $10.0 \%$ & $53.3 \%$ & $16.7 \%$ & $6.7 \%$ \\
\hline $\begin{array}{l}\text { Accounting education in Kosovo } \\
\text { does not meet the basic criteria } \\
\text { of SNEs }\end{array}$ & $22.2 \%$ & $13.9 \%$ & $36.1 \%$ & $22.2 \%$ & $5.6 \%$ & $10.0 \%$ & $10.0 \%$ & $23.3 \%$ & $36.7 \%$ & $20.0 \%$ \\
\hline $\begin{array}{l}\text { Accounting education in Kosovo } \\
\text { does not enable the training of } \\
\text { students in Kosovo in relation to } \\
\text { SNEs }\end{array}$ & $22.2 \%$ & $5.6 \%$ & $25.0 \%$ & $44.4 \%$ & $2.8 \%$ & $3.3 \%$ & $6.7 \%$ & $43.3 \%$ & $30.0 \%$ & $16.7 \%$ \\
\hline $\begin{array}{l}\text { Accounting education in Kosovo } \\
\text { has a significant lack of achieve- } \\
\text { ment of SNEs }\end{array}$ & $11.1 \%$ & $27.8 \%$ & $33.3 \%$ & $27.8 \%$ & $0.0 \%$ & $3.3 \%$ & $13.3 \%$ & $50.0 \%$ & $13.3 \%$ & $20.0 \%$ \\
\hline $\begin{array}{l}\text { The implementation of account- } \\
\text { ing education programs in higher } \\
\text { education is not implemented in } \\
\text { practice }\end{array}$ & $13.9 \%$ & $27.8 \%$ & $27.8 \%$ & $19.4 \%$ & $11.1 \%$ & $20.0 \%$ & $10.0 \%$ & $30.0 \%$ & $30.0 \%$ & $10.0 \%$ \\
\hline $\begin{array}{l}\text { Higher education curricula and } \\
\text { syllabi do not comply with Ko- } \\
\text { sovo and SNE accounting educa- } \\
\text { tion standards }\end{array}$ & $13.9 \%$ & $16.7 \%$ & $30.6 \%$ & $27.8 \%$ & $11.1 \%$ & $6.7 \%$ & $3.3 \%$ & $60.0 \%$ & $10.0 \%$ & $20.0 \%$ \\
\hline
\end{tabular}

In matching the curricula of higher and secondary education in Kosovo with SNEs, we see that in the university there is a relative lack of coherence between the programs and the SNEs, while in vocational high schools most think that there is no coherence between programs and SNEs.

Table 16

Compatibility of higher and secondary education curriculum in Kosovo concerning international education standards (SNE)

\begin{tabular}{|c|c|c|c|c|c|c|c|c|c|c|}
\hline & \multicolumn{10}{|c|}{ Groups } \\
\hline & \multicolumn{5}{|c|}{ Universities } & \multicolumn{5}{|c|}{ Universities } \\
\hline & $\begin{array}{c}\text { I do not } \\
\text { agree at all }\end{array}$ & $\begin{array}{l}\text { I don't } \\
\text { know }\end{array}$ & Neutral & Agree & Agree & $\begin{array}{c}\text { I do not } \\
\text { agree at all }\end{array}$ & $\begin{array}{c}\text { I do not } \\
\text { know }\end{array}$ & Neutral & Agree & Agree \\
\hline & $\%$ & $\%$ & $\%$ & $\%$ & $\%$ & $\%$ & $\%$ & $\%$ & $\%$ & $\%$ \\
\hline $\begin{array}{l}\text { Accounting education curricula } \\
\text { in higher education do not have } \\
\text { coherence of application in prac- } \\
\text { tice }\end{array}$ & $8.3 \%$ & $22.2 \%$ & $22.2 \%$ & $36.1 \%$ & $11.1 \%$ & $0.0 \%$ & $13.3 \%$ & $23.3 \%$ & $16.7 \%$ & $46.7 \%$ \\
\hline $\begin{array}{l}\text { Accounting education curricula } \\
\text { in higher education need to be } \\
\text { adapted to SNEs }\end{array}$ & $0.0 \%$ & $0.0 \%$ & $25.0 \%$ & $11.1 \%$ & $63.9 \%$ & $0.0 \%$ & $16.7 \%$ & $50.0 \%$ & $13.3 \%$ & $20.0 \%$ \\
\hline $\begin{array}{l}\text { There is a significant lack of im- } \\
\text { plementation of programs and } \\
\text { curricula in higher education, in } \\
\text { the framework of accounting ed- } \\
\text { ucation }\end{array}$ & $13.9 \%$ & $33.3 \%$ & $5.6 \%$ & $41.7 \%$ & $5.6 \%$ & $6.7 \%$ & $16.7 \%$ & $36.7 \%$ & $16.7 \%$ & $23.3 \%$ \\
\hline $\begin{array}{l}\text { Curricula and programs at the } \\
\text { higher level of education do not } \\
\text { offer practical implementation } \\
\text { opportunities }\end{array}$ & $5.6 \%$ & $30.6 \%$ & $38.9 \%$ & $13.9 \%$ & $11.1 \%$ & $3.3 \%$ & $16.7 \%$ & $43.3 \%$ & $23.3 \%$ & $13.3 \%$ \\
\hline
\end{tabular}

In the context of accounting education, it is said that there is a significant lack of implementation of accounting education, but the curricula and programs are not very appropriate, but most deny and say that they do not agree with these statements. Most disagree that continuing education is not in line with SNEs, and it is said that accounting education organizations are also to some extent conforming accounting education to SNEs. The practice in some cases is considered impossible to implement and adapt to the SNEs.

What you do not like is that the implementation of the standards is realized for some only for some parts of the programs and not in full, but the vocational schools of accounting education do not offer opportunities to continue the professional education. They think that there is coherence between accounting education and practical application and that higher and secondary education curricula need to be more in line with SNEs. 
Table 17

Continuation of vocational education in accordance with international education standards (SNE)

\begin{tabular}{|c|c|c|c|c|c|c|c|c|c|c|}
\hline & \multicolumn{10}{|c|}{ Groups } \\
\hline & \multicolumn{5}{|c|}{ Universities } & \multicolumn{5}{|c|}{ Universities } \\
\hline & $\begin{array}{c}\text { I do not } \\
\text { agree at all }\end{array}$ & $\begin{array}{l}\text { I don't } \\
\text { know }\end{array}$ & Neutral & Agree & Agree & $\begin{array}{c}\text { I do not } \\
\text { agree at all }\end{array}$ & $\begin{array}{c}\text { I do not } \\
\text { know }\end{array}$ & Neutral & Agree & Agree \\
\hline & $\%$ & $\%$ & $\%$ & $\%$ & $\%$ & $\%$ & $\%$ & $\%$ & $\%$ & $\%$ \\
\hline $\begin{array}{l}\text { Continuing education in accounting } \\
\text { education in Kosovo is not in line } \\
\text { with SNEs }\end{array}$ & $22.2 \%$ & $27.8 \%$ & $19.4 \%$ & $22.2 \%$ & $8.3 \%$ & $3.3 \%$ & $26.7 \%$ & $36.7 \%$ & $23.3 \%$ & $10.0 \%$ \\
\hline $\begin{array}{l}\text { Accounting education organizations } \\
\text { are failing to meet the required stand- } \\
\text { ards with higher education programs } \\
\text { and curricula in Kosovo }\end{array}$ & $2.8 \%$ & $38.9 \%$ & $30.6 \%$ & $16.7 \%$ & $11.1 \%$ & $16.7 \%$ & $23.3 \%$ & $40.0 \%$ & $6.7 \%$ & $13.3 \%$ \\
\hline $\begin{array}{l}\text { Continuing education does not pro- } \\
\text { vide opportunities for accounting ed- } \\
\text { ucation in practice }\end{array}$ & $19.4 \%$ & $22.2 \%$ & $38.9 \%$ & $5.6 \%$ & $13.9 \%$ & $0.0 \%$ & $23.3 \%$ & $36.7 \%$ & $16.7 \%$ & $23.3 \%$ \\
\hline $\begin{array}{l}\text { The implementation of standards is } \\
\text { realized only for a part of the pro- } \\
\text { grams and not in the whole }\end{array}$ & $5.6 \%$ & $13.9 \%$ & $50.0 \%$ & $13.9 \%$ & $16.7 \%$ & $20.0 \%$ & $16.7 \%$ & $36.7 \%$ & $16.7 \%$ & $10.0 \%$ \\
\hline $\begin{array}{l}\text { Vocational schools of accounting ed- } \\
\text { ucation do not offer opportunities for } \\
\text { continuing vocational education }\end{array}$ & $75.0 \%$ & $0.0 \%$ & $0.0 \%$ & $0.0 \%$ & $25.0 \%$ & $20.0 \%$ & $10.0 \%$ & $40.0 \%$ & $10.0 \%$ & $20.0 \%$ \\
\hline
\end{tabular}

Table 18

The impact of account education on increasing the quality of accounting and auditing services

\begin{tabular}{|c|c|c|c|c|c|c|c|c|c|c|}
\hline & \multicolumn{10}{|c|}{ Groups } \\
\hline & \multicolumn{5}{|c|}{ Universities } & \multicolumn{5}{|c|}{ Universities } \\
\hline & $\begin{array}{c}\text { I do not } \\
\text { agree at all }\end{array}$ & $\begin{array}{l}\text { I don't } \\
\text { know }\end{array}$ & Neutral & Agree & Agree & $\begin{array}{c}\text { I do not } \\
\text { agree at all }\end{array}$ & $\begin{array}{c}\text { I do not } \\
\text { know }\end{array}$ & Neutral & Agree & Agree \\
\hline & $\%$ & $\%$ & $\%$ & $\%$ & $\%$ & $\%$ & $\%$ & $\%$ & $\%$ & $\%$ \\
\hline $\begin{array}{l}\text { Accounting education in higher educa- } \\
\text { tion affects the increase of the quality of } \\
\text { accounting services }\end{array}$ & $47.2 \%$ & $11.1 \%$ & $16.7 \%$ & $13.9 \%$ & $11.1 \%$ & $50.0 \%$ & $13.3 \%$ & $16.7 \%$ & $13.3 \%$ & $6.7 \%$ \\
\hline $\begin{array}{l}\text { Accounting education in higher educa- } \\
\text { tion increases the quality of auditor ser- } \\
\text { vices }\end{array}$ & $52.8 \%$ & $5.6 \%$ & $30.6 \%$ & $5.6 \%$ & $5.6 \%$ & $56.7 \%$ & $6.7 \%$ & $30.0 \%$ & $3.3 \%$ & $3.3 \%$ \\
\hline $\begin{array}{l}\text { Organizations that provide accounting } \\
\text { education services, affect the increase } \\
\text { of the quality of accounting services }\end{array}$ & $0.0 \%$ & $0.0 \%$ & $5.6 \%$ & $19.4 \%$ & $75.0 \%$ & $0.0 \%$ & $0.0 \%$ & $3.3 \%$ & $16.7 \%$ & $80.0 \%$ \\
\hline $\begin{array}{l}\text { Organizations that provide accounting } \\
\text { education services increase the quality } \\
\text { of auditor services }\end{array}$ & $0.0 \%$ & $0.0 \%$ & $33.3 \%$ & $5.6 \%$ & $61.1 \%$ & $0.0 \%$ & $0.0 \%$ & $26.7 \%$ & $6.7 \%$ & $66.7 \%$ \\
\hline $\begin{array}{l}\text { There is no coherence between institu- } \\
\text { tions providing co-educational educa- } \\
\text { tion services and the quality of account- } \\
\text { ing and auditing }\end{array}$ & $0.0 \%$ & $0.0 \%$ & $11.1 \%$ & $36.1 \%$ & $52.8 \%$ & $0.0 \%$ & $0.0 \%$ & $10.0 \%$ & $36.7 \%$ & $53.3 \%$ \\
\hline
\end{tabular}

Regarding the implementation of accounting education reforms, we see that reforms in accounting education are considered necessary, as in all cases teachers say that there should be implementation and that this is happening.

Table 19

Implementation of accounting reforms in continuing vocational education (continuing education)

\begin{tabular}{|c|c|c|c|c|c|c|c|c|c|c|}
\hline & \multicolumn{10}{|c|}{ Groups } \\
\hline & \multicolumn{5}{|c|}{ Universities } & \multicolumn{5}{|c|}{ Universities } \\
\hline & $\begin{array}{c}\text { I do not } \\
\text { agree at all }\end{array}$ & $\begin{array}{l}\text { I don't } \\
\text { know }\end{array}$ & Neutral & Agree & Agree & $\begin{array}{c}\text { I do not } \\
\text { agree at all }\end{array}$ & $\begin{array}{c}\text { I do not } \\
\text { know }\end{array}$ & Neutral & Agree & Agree \\
\hline & $\%$ & $\%$ & $\%$ & $\%$ & $\%$ & $\%$ & $\%$ & $\%$ & $\%$ & $\%$ \\
\hline $\begin{array}{l}\text { Education reforms in Kosovo in } \\
\text { terms of accounting education are not } \\
\text { implemented }\end{array}$ & $11.1 \%$ & $13.9 \%$ & $30.6 \%$ & $22.2 \%$ & $22.2 \%$ & $13.3 \%$ & $13.3 \%$ & $30.0 \%$ & $20.0 \%$ & $23.3 \%$ \\
\hline $\begin{array}{l}\text { There is a strong possibility of non- } \\
\text { implementation of reforms in higher } \\
\text { education in Kosovo }\end{array}$ & $5.6 \%$ & $16.7 \%$ & $41.7 \%$ & $27.8 \%$ & $8.3 \%$ & $6.7 \%$ & $20.0 \%$ & $40.0 \%$ & $26.7 \%$ & $6.7 \%$ \\
\hline $\begin{array}{l}\text { Higher education institutions in Ko- } \\
\text { sovo are failing to address educa- } \\
\text { tional reforms in continuing voca- } \\
\text { tional education }\end{array}$ & $0.0 \%$ & $25.0 \%$ & $41.7 \%$ & $11.1 \%$ & $22.2 \%$ & $0.0 \%$ & $30.0 \%$ & $40.0 \%$ & $10.0 \%$ & $20.0 \%$ \\
\hline $\begin{array}{l}\text { Accounting education organizations } \\
\text { in Kosovo are not implementing ed- } \\
\text { ucation reforms }\end{array}$ & $2.8 \%$ & $16.7 \%$ & $33.3 \%$ & $16.7 \%$ & $30.6 \%$ & $3.3 \%$ & $20.0 \%$ & $33.3 \%$ & $13.3 \%$ & $30.0 \%$ \\
\hline $\begin{array}{l}\text { Accounting education reforms do not } \\
\text { support accounting education service } \\
\text { organizations }\end{array}$ & $11.1 \%$ & $13.9 \%$ & $47.2 \%$ & $8.3 \%$ & $19.4 \%$ & $13.3 \%$ & $13.3 \%$ & $46.7 \%$ & $10.0 \%$ & $16.7 \%$ \\
\hline
\end{tabular}




\subsection{Factor analysis and SEM- Structural Equation Modeling}

Factor analysis was conducted to determine the factors that affect accounting education in Kosovo. The table below shows that 8 of the components have reached the Eigenvalue value above 1, with values from 7,484 to 1,226 of the Eigenvalue value. This means that the data are classified into eight factors.

Table 20

Total Variance Explained

\begin{tabular}{|c|c|c|c|c|c|c|c|c|c|}
\hline \multirow[b]{2}{*}{ Component } & \multicolumn{3}{|c|}{ Initial Eigenvalues } & \multicolumn{3}{|c|}{ Extraction Sums of Squared Loadings } & \multicolumn{3}{|c|}{ Rotation Sums of Squared Loadings } \\
\hline & Total & $\begin{array}{c}\% \text { of Vari- } \\
\text { ance }\end{array}$ & Cumulative $\%$ & Total & $\begin{array}{l}\text { of Vari- } \\
\text { ance }\end{array}$ & Cumulative $\%$ & Total & $\begin{array}{l}\text { of Vari- } \\
\text { ance }\end{array}$ & Cumulative $\%$ \\
\hline 1 & 7.484 & 24.142 & 24.142 & 7.484 & 24.142 & 24.142 & 5.015 & 16.176 & 16.176 \\
\hline 2 & 5.607 & 18.087 & 42.229 & 5.607 & 18.087 & 42.229 & 4.661 & 15.036 & 31.213 \\
\hline 3 & 3.163 & 10.204 & 52.433 & 3.163 & 10.204 & 52.433 & 3.264 & 10.528 & 41.741 \\
\hline 4 & 2.374 & 7.657 & 60.089 & 2.374 & 7.657 & 60.089 & 3.031 & 9.778 & 51.520 \\
\hline 5 & 1.797 & 5.795 & 65.885 & 1.797 & 5.795 & 65.885 & 2.801 & 9.036 & 60.556 \\
\hline 6 & 1.588 & 5.124 & 71.009 & 1.588 & 5.124 & 71.009 & 2.490 & 8.031 & 68.587 \\
\hline 7 & 1.478 & 4.768 & 75.777 & 1.478 & 4.768 & 75.777 & 1.779 & 5.740 & 74.326 \\
\hline 8 & 1.226 & 3.953 & 79.730 & 1.226 & 3.953 & 79.730 & 1.675 & 5.404 & 79.730 \\
\hline 9 & 0.928 & 2.993 & 82.723 & & & & & & \\
\hline 10 & 0.812 & 2.619 & 85.342 & & & & & & \\
\hline 11 & 0.642 & 2.072 & 87.415 & & & & & & \\
\hline 12 & 0.593 & 1.911 & 89.326 & & & & & & \\
\hline 13 & 0.547 & 1.765 & 91.091 & & & & & & \\
\hline 14 & 0.457 & 1.475 & 92.566 & & & & & & \\
\hline 15 & 0.425 & 1.371 & 93.937 & & & & & & \\
\hline 16 & 0.364 & 1.173 & 95.110 & & & & & & \\
\hline 17 & 0.293 & 0.945 & 96.055 & & & & & & \\
\hline 18 & 0.240 & 0.773 & 96.828 & & & & & & \\
\hline 19 & 0.216 & 0.695 & 97.523 & & & & & & \\
\hline 20 & 0.177 & 0.571 & 98.094 & & & & & & \\
\hline 21 & 0.144 & 0.464 & 98.558 & & & & & & \\
\hline 22 & 0.111 & 0.357 & 98.915 & & & & & & \\
\hline 23 & 0.098 & 0.315 & 99.231 & & & & & & \\
\hline 24 & 0.087 & 0.281 & 99.512 & & & & & & \\
\hline 25 & 0.057 & 0.185 & 99.697 & & & & & & \\
\hline 26 & 0.038 & 0.122 & 99.819 & & & & & & \\
\hline 27 & 0.025 & 0.080 & 99.899 & & & & & & \\
\hline 28 & 0.016 & 0.053 & 99.952 & & & & & & \\
\hline 29 & 0.008 & 0.027 & 99.979 & & & & & & \\
\hline 30 & 0.007 & 0.021 & 100.000 & & & & & & \\
\hline 31 & $-8.666 \mathrm{E}-16$ & $-2.796 \mathrm{E}-15$ & 100.000 & & & & & & \\
\hline
\end{tabular}

Extraction Method: Principal Component Analysis.

The graph confirms that after the eighth component the decline has begun, which means that our variables will be classified into eight major components.

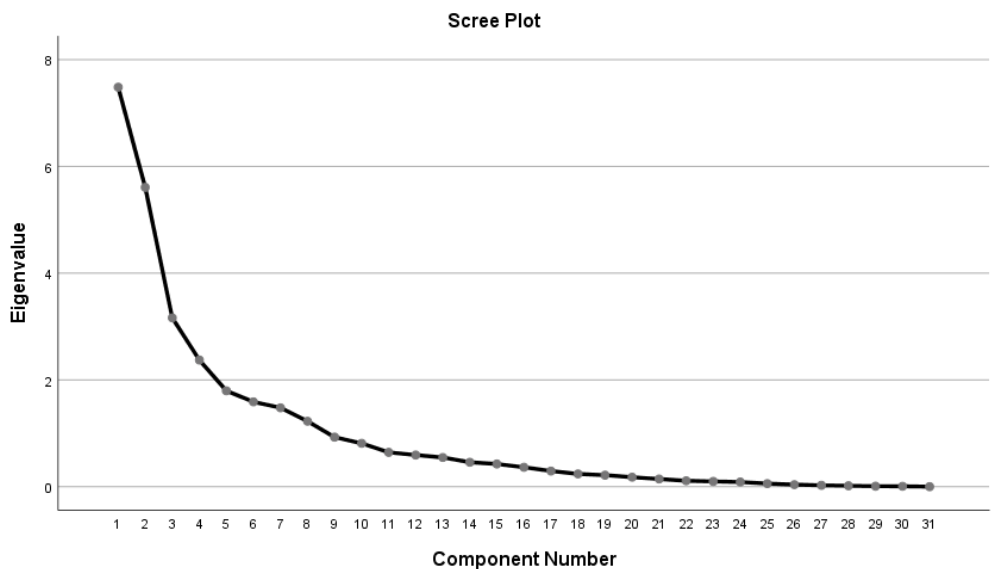

Fig. 2. The results of Scree plot 
Table 21 lists the variables that have reached a value above 0.60 of the correlation coefficient. The variables are separated in the first component (Accounting education in Kosovo does not enable the training of students in Kosovo in relation to SNES $=0.643$, The implementation of accounting education programs in higher education is not implemented in practice $=0.772$, Higher education curricula and syllabi do not comply with Kosovo and SNE accounting education standards $=0.788$,

Table 21

Rotated Component Matrix

Accounting education in Kosovo needs to be changed to adapt to SNEs

Accounting education in Kosovo does not meet the basic criteria of SNEs

Accounting education in Kosovo does not enable the training of students in Kosovo concerning SNEs $\quad 0.643$

Accounting education in Kosovo has a significant lack of achievement of SNEs

The implementation of accounting education programs in higher education is not implemented in practice 0.772

Higher education curricula and syllabi do not comply with Kosovo and SNE accounting education stand-

ards

Accounting education curricula in higher education do not have coherence of application in practice

Accounting education curricula in higher education need to be adapted to SNEs

There is a significant lack of implementation of programs and curricula in higher education, in the frame- 0.765

work of accounting education

Curricula and programs at the higher level of education do not offer practical implementation opportunities 0.728

Continuing education in accounting education in Kosovo is not in line with SNEs

Accounting education organizations are failing to meet the required standards with higher education pro- 0.692

grams and curricula in Kosovo

Continuing education does not provide opportunities for accounting education in practice

The implementation of standards is realized only for a part of the programs and not in the whole

Vocational schools of accounting education do not offer opportunities for continuing vocational education

Accounting education in higher education affects the increase of the quality of accounting services

Accounting education in higher education increases the quality of auditor services

Organizations that provide accounting education services, affect the increase of the quality of accounting

services

Organizations that provide accounting education services increase the quality of auditor services

There is no coherence between institutions providing co-educational education services and the quality of

accounting and auditing

Education reforms in Kosovo in terms of accounting education are not implemented

There is a strong possibility of non-implementation of reforms in higher education in Kosovo

Higher education institutions in Kosovo are failing to address educational reforms in continuing vocational

education

Accounting education organizations in Kosovo are not implementing education reforms

Accounting education reforms do not support accounting education service organizations

Higher accounting education curricula in Kosovo need to be adapted to SNEs

Education reforms in Kosovo in terms of accounting education are not implemented

There is a strong possibility of non-implementation of reforms in higher education in Kosovo

Higher education institutions in Kosovo are failing to address educational reforms in continuing vocational

education

Accounting education organizations in Kosovo are not implementing education reforms

Accounting education reforms do not support accounting education service organizations

Extraction Method: Principal Component Analysis.

Rotation Method: Varimax with Kaiser Normalization.

a. Rotation converged in 9 iterations.

Accounting education curricula in higher education do not have coherence of application in practice $=0.741$, There is a significant lack of implementation of programs and curricula in higher education, in the framework of accounting education $=0.765$, Curricula and programs at the higher level of education do not offer practical implementation opportunities $=0.728$ and Accounting education organizations are failing to meet the required standards with higher education programs and curricula in Kosovo=0.692 ) which means that the first factor that affects the compatibility of accounting education has to do with the changes that need to be undertaken, the criteria met, the conditions that are offered within accounting education need to be adjusted and improved. In the second component the variables are separated (There is a strong possibility of non-implementation of reforms in higher education in Kosovo $=0.928$, Higher education institutions in Kosovo are failing to address educational reforms in continuing vocational education $=0.939$, Accounting education organizations in Kosovo are not implementing education reforms $=0.909$ the Accounting education reforms do not support accounting education service organizations $=0.939$ ), this component is related to the changes in accounting education in Kosovo, namely the curricula, educational programs, subject programs and the continuation of accounting education. In the third component the variables are classified (Accounting education in higher education affects the increase of the quality of accounting services $=0.663$, Accounting education in higher education increases the quality of auditor services $=0.738$ the Education reforms in Kosovo in terms of accounting education are not implemented $=0.818$ ). In the fourth component the variables are separated ( Organizations that provide accounting education services, affect the increase of the quality of accounting services $=0.886$, Higher accounting education curricula in Kosovo need to be adapted to SNEs $=0.785$ and Education reforms in Kosovo in terms of accounting education are not implemented $=0.742$ ). The fifth component is separated ( There is no coherence between institutions providing co-educational education services and the quality of accounting and auditing $=0.626$, There is a strong possibility of non-implementation of reforms in higher education in Kosovo $=0.668$, Higher education institutions in Kosovo are failing to address educational reforms in continuing vocational education $=0.689$ and Accounting education organizations in Kosovo are not implementing education reforms $=0.931$ ). 
In the sixth component we separate the variable ( Continuing education does not provide opportunities for accounting education in practice $=0.823$ ), then to the seventh component (Accounting education in Kosovo does not meet the basic criteria of SNEs $=0.801$ ) and to the eighth component (Accounting education in Kosovo needs to be changed to adapt to SNEs $=0.860)$.

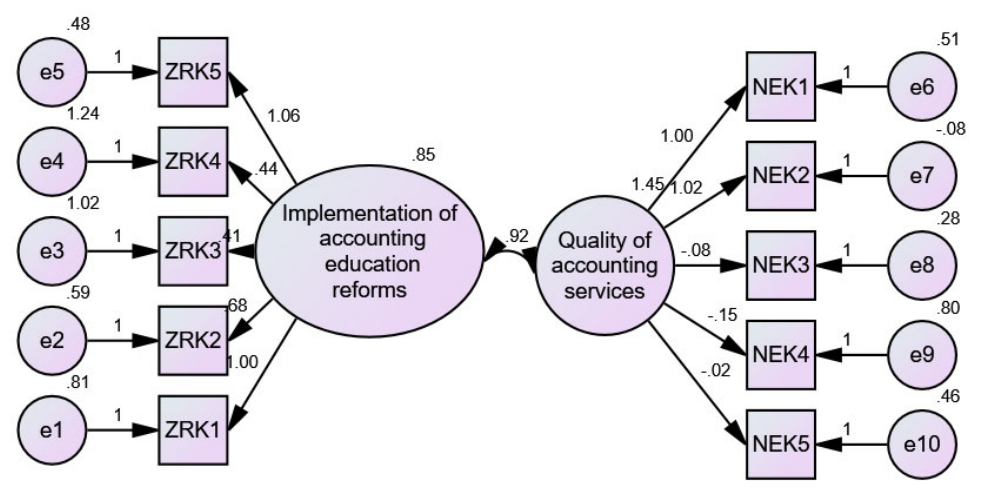

Fig. 3. The results of the SEM implementation of accounting education-Quality of accounting services

The following analysis clearly shows the outcome and the link between the two main components of the research, that of the implementation of accounting education reforms and the impact that these reforms have on the quality of accounting services.

Table 22

The results of Organizational Justice Scale Adaptation Indexes

\begin{tabular}{lccccccc}
\hline \multicolumn{2}{c}{$\chi^{2}$} & $d f$ & $\chi 2 / d f$ & RMSEA & TLI & CFI & $\begin{array}{c}\text { Probability } \\
\text { Level }\end{array}$ \\
\hline Original model & 325,255 & 34 & 2.824 & .363 & .435 & .423 & .000 \\
\hline$\chi^{2}=$ Chi-Square; & df=Degree of Freedom, RMSEA= Root Mean Square Error of Approximation; & & & &
\end{tabular}

Based on the above results, the regression and correlation analysis are performed, which are presented below, and also present the research results.

\subsection{Linear regression}

Implementation of reforms in the field of accounting education and adaptation to SNEs, has an impact on the quality of accounting services

To validate the hypothesis, linear regression is used which is classified in high school and university schools. So, the aim is to measure the impact of reforms and curricular adaptation to SNEs and the impact that this has on improving the quality of accounting services in Kosovo, which are provided in different forms and levels. The independent variable is the implementation of accounting education reforms, while the dependent variable is the quality of accounting services in Kosovo.

Table 23

The summary of regression analysis

\begin{tabular}{|c|c|c|c|c|}
\hline \multicolumn{5}{|c|}{ High School } \\
\hline \multirow{2}{*}{ Independent variable } & \multicolumn{4}{|c|}{ Model 1} \\
\hline & B & S.H & $\beta$ & Sig. \\
\hline Implementation of accounting education reforms & 0.517 & 0.081 & 0.738 & 0.000 \\
\hline $\mathrm{R}$ & \multicolumn{4}{|c|}{0.738} \\
\hline $\mathrm{R}^{2}$ & \multicolumn{4}{|c|}{0.545} \\
\hline$\Delta \mathrm{R}^{2}$ & \multicolumn{4}{|c|}{0.531} \\
\hline ANOVA (Sig.) & \multicolumn{4}{|c|}{0.000} \\
\hline \multicolumn{5}{|l|}{ Dependent variable: Quality of accounting services } \\
\hline \multicolumn{5}{|c|}{ Universities } \\
\hline & \multicolumn{4}{|c|}{ Model 1} \\
\hline Independent variable & $\mathrm{B}$ & S.H & $\beta$ & Sig. \\
\hline Implementation of accounting education reforms & 0.480 & 0.082 & 0.740 & 0.000 \\
\hline $\mathrm{R}$ & \multicolumn{4}{|c|}{0.740} \\
\hline $\mathrm{R}^{2}$ & \multicolumn{4}{|c|}{0.548} \\
\hline$\Delta \mathrm{R}^{2}$ & \multicolumn{4}{|c|}{0.532} \\
\hline ANOVA (Sig.) & \multicolumn{4}{|c|}{0.000} \\
\hline
\end{tabular}


Based on the research results, we see that in the middle level of vocational schools we have the results $(\mathrm{B}=0.517, \mathrm{SH}=0.081$, $\beta=0.738$ ) with regression $R=0.738$, then regression raised in squares $R^{2}=0.531$ and significance $p$ - value $=0.000$ which is significant at 0.01 of the confidence level. The result is also similar at the university level, i.e. $(\mathrm{B}=0.740, \mathrm{~S} . \mathrm{H}=0.548, \beta=$ 0.0 .740 ) with regression $R=0.740$, then regression raised to squares $R^{2}=0.548$ and significance $p$-value $=0.000$. So, the more we implement the reforms in accounting education in Kosovo, implementing the adaptation of the curriculum with SNEs, the adaptation of syllabi to the curriculum, and the changes in accounting education, then we will have a high level of success of services of the accounting. This is happening at both the middle and upper echelon levels, indicating that it is a factor to be taken into account by institutions in Kosovo, with a proactive approach to delaying accounting education reforms. Disseminating the impact of reforms on the quality of accounting services. With this we can conclude that we accept the hypothesis that the implementation of reforms in the framework of accounting education and compliance with SNEs, has an impact on the quality of accounting services, $p$-value $<0.01$.
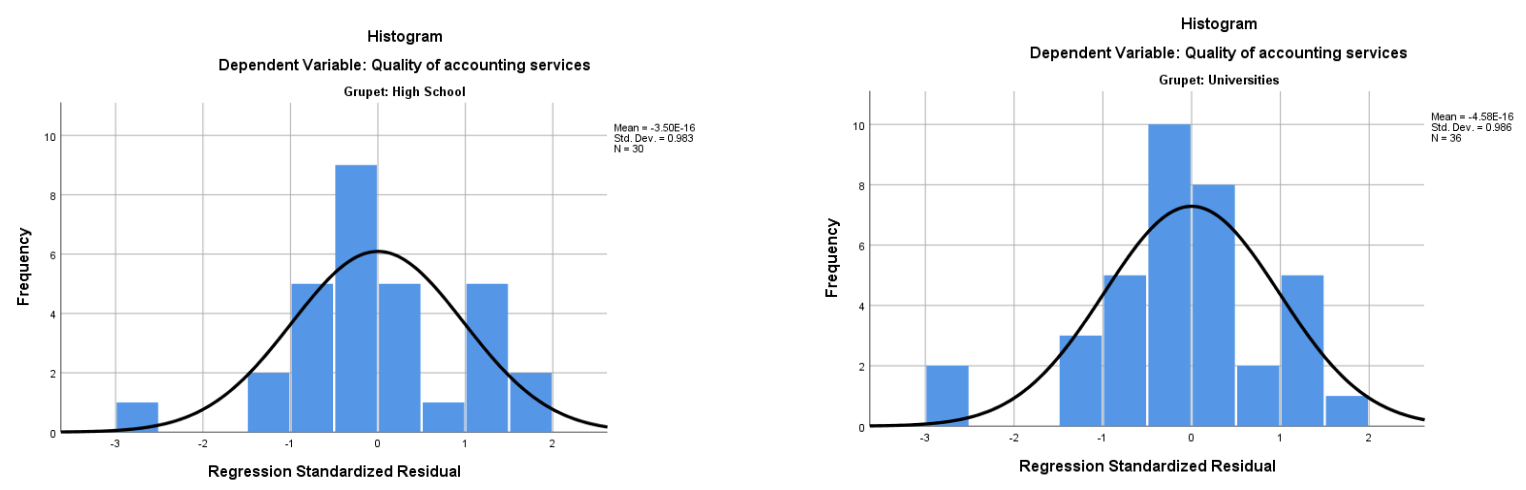

Fig. 4. The results of residuals for the regression analysis

\subsection{Correlation}

Through correlation analysis we are presenting the relationship between reforms and the quality of accounting services, so the independent variable is reform, while the dependent one is the quality of accounting services.

Table 24

Correlation

\begin{tabular}{|c|c|c|c|c|}
\hline & Groups & & & $\begin{array}{l}\text { Quality of account- } \\
\text { ing services }\end{array}$ \\
\hline \multirow[t]{6}{*}{ Spearman's rho } & \multirow{3}{*}{ Universities } & \multirow{6}{*}{$\begin{array}{l}\text { Implementation of accounting educa- } \\
\text { tion reforms }\end{array}$} & Correlation Coefficient & $0.628^{* * k}$ \\
\hline & & & Sig. (2-tailed) & 0.000 \\
\hline & & & $\mathrm{N}$ & 36 \\
\hline & \multirow{3}{*}{ High school } & & Correlation Coefficient & $0.652^{* * *}$ \\
\hline & & & Sig. (2-tailed) & 0.000 \\
\hline & & & $\mathrm{N}$ & 30 \\
\hline
\end{tabular}

Based on the above results we see that we have a high positive correlation between accounting education reforms and the quality of services in secondary education $(\mathrm{Rho}=.628, \mathrm{p}$-value $=0.000)$, and in university $(\mathrm{Rho}=.652, \mathrm{p}$-value $=0.000)$. With this we conclude that the implementation of accounting education reforms has a significant relationship with the quality of accounting services in Kosovo, p-value $<0.01$.
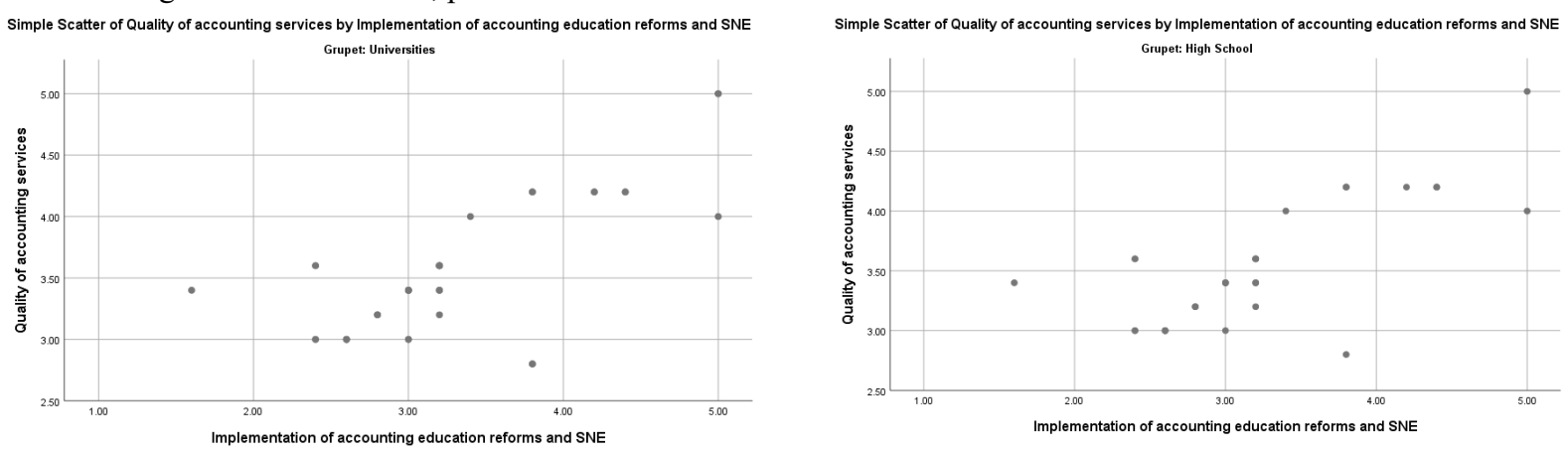

Fig. 5. The results of Simple Scatter of Quality of accounting services by implementation of accounting education reforms and SNE 


\section{Conclusion and recommendation}

The research was conducted with university professors of accounting education and professors of accounting subjects of high schools in Kosovo. The purpose was to measure their opinion on the implementation of accounting education reforms and the impact they have on improving the quality of accounting services in Kosovo. The first results of the research show that teachers of universities and high schools have sufficient knowledge on the standards of international education to SNEs and express that there is compliance with SNEs and their curricular programs in the field of accounting. We understand that the support from the responsible bodies is not very good and for this, we have come up with a recommendation that the competent bodies in Kosovo should take more seriously the implementation of accounting education reforms. They think that more appropriate conditions for accounting education should be created. Curricula in Kosovo have a wide range of accounting education and this shows that it is on the right track, but support is needed to support them. Regarding the compliance of accounting education in Kosovo with SNEs, we see that both parties agree that we have a good level of compliance and that continuing education in the field of accounting is a very important factor. The results of linear regression show that the implementation of reforms is significantly affecting the quality of accounting services in Kosovo p-value $<0.01$, while the correlation analysis shows that there is a significant correlation between the implementation of reforms and the quality of services of the accounting. Based on the results of the research I can recommend that the competent bodies be more attentive in the implementation of accounting education reforms in Kosovo, align all accounting education programs in Kosovo with SNEs, and monitor the implementation of reforms, as this has a significant impact on the quality of accounting services in Kosovo.

\section{References}

Bergner, J., Filzen, J. J., \& Simkin, M. G. (2016). Why use multiple choice questions with excess information?. Journal of Accounting Education, 34, 1-12.

Burnett, S. (2003). The future of accounting education: A regional perspective. Journal of Education for Business, 78(3), 129134.

Dugger, W. M. (1980). Power: an institutional framework of analysis. Journal of Economic Issues, 14(4), 897-907.

Edwards, J. R. (2011). Accounting education in Britain during the early modern period. Accounting History Review, 21(1), 37-67.

Evans, L. (2011). The scholarship of researcher development: Mapping the terrain and pushing back boundaries. International Journal for Researcher Development, 2(2).

Gaffikin, M. J. (2008). Accounting theory: Research, regulation and accounting practice.

Langenderfer, H. Q. (1987). Accounting Education's History--A 100-Year Search for Identity. Journal of Accountancy, $163(5), 302$.

Iatridis, G. (2010). International Financial Reporting Standards and the quality of financial statement information. International Review of Financial Analysis, 19(3), 193-204.

Lindsay, H. (2016). More than 'continuing professional development': A proposed new learning framework for professional accountants. Accounting Education, 25(1), 1-13.

Mayper, A. G., Pavur, R. J., Merino, B. D., \& Hoops, W. (2005). The impact of accounting education on ethical values: An institutional perspective. Accounting and the Public Interest, 5(1), 32-55.

Moyes, G. D., Williams, P. A., \& Quigley, B. Z. (2000). The Relation between Perceived Treatment Discrimination and Job Satisfaction among African-American Accounting Professionals. Accounting Horizons, 14(1), 21-48.

Noble, H., \& Smith, J. (2015). Issues of validity and reliability in qualitative research. Evidence-Based Nursing, 18(2), 34-35.

Parker, L. D., Guthrie, J., \& Linacre, S. (2011). The relationship between academic accounting research and professional practice. Accounting, Auditing \& Accountability Journal, 24(1).

Parker, L. D. (2007). Professionalisation and UK accounting education: Academic and professional complicity-A commentary on 'Professionalizing claims and the state of UK professional accounting education: Some evidence'. Accounting Education: an international journal, 16(1), 43-46.

Sangster, A., \& Scataglinibelghitar, G. (2010). Luca Pacioli: the father of accounting education. Accounting Education: An International Journal, 19(4), 423-438.

Sangster, A. (2015). The Reckoning: Financial Accountability and the Making and Breaking of Nations.

Sikka, P., Haslam, C., Kyriacou, O., \& Agrizzi, D. (2007). Professionalizing claims and the state of UK professional accounting education: some evidence. Accounting Education: An International Journal, 16(1), 3-21.

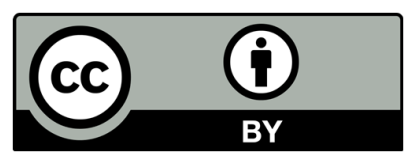

(C) 2021 by the authors; licensee Growing Science, Canada. This is an open access article distributed under the terms and conditions of the Creative Commons Attribution (CC-BY) license (http://creativecommons.org/licenses/by/4.0/). 